\title{
KNOWLEDGE OF PREGNANT WOMEN IN THE THIRD TRIMESTER ABOUT CONGENITAL DEAFNESS AND FREQUENCY OF ANTENATAL CARE DURING THE COVID-19 PANDEMIC
}

\author{
Nicha Karmila Tamtiana ${ }^{1}$, Nyilo Purnami2 ${ }^{*}$, and Endyka Erye Frety ${ }^{1,3}$ \\ ${ }^{1}$ Department of Midwifery Education, Faculty of Medicine University Airlangga 60132, Surabaya, East Java, Indonesia \\ ${ }^{2}$ Department of Ear Nose Throat-Head and Neck Surgery, Faculty of Medicine University Airlangga 60132, Surabaya, East Java, \\ Indonesia \\ ${ }^{2}$ Email : nyilo@fk.unair.ac.id
}

\begin{abstract}
Background: In Indonesia, the prevalence of hearing loss in $4.2 \%$ and the prevalence of congenital deafness is $0.1 \%$. WHO estimates that about $60 \%$ of hearing loss in caused by causes that can be prevented through improved maternal and child health practice from routine ANC visits and screening for pregnancy complications. During the COVID-19 pandemic, pregnant women are afraid to do a pregnancy check, the frequency of ANC is irregular which will affect the health of the fetus in the womb. Methods: The research method is observational analysis with a cross-sectional approach. The sample size is 110 pregnant women in the third trimester with phsysiological pregnancies and willing to be respondents. The sampling technique was purposive sampling. Data were analyzed using a chi-square statistical test. Result: The result of the analysis showed that $49.1 \%$ of mothers had good knowledge of congenital deafness, $28.25 \%$ had poor knowledge, and $22.7 \%$ had sufficient knowledge. As many as $76.4 \%$ of mothers made ANC visits not according to standars and only $26(23.6 \%)$ mothers made ANC visits according to standard. The result of the statistical analysis test it has been shown that there is an association between knowledge of pregnant women in the third trimester about congenital deafness with the frequency of antenatal care during the COVID-19 pandemic with $p$-value $=0.029(\mathrm{p}<0.05)$. Conclusion: There is a link between the knowledge of pregnant women in the third trimester about congenital deafness with the frequency of antenatal care during the COVID-19 pandemic. The COVID-19 pandemic has prevented pregnant women from carrying out ANC in health service and increased the anxiety of pregnant women.
\end{abstract}

Keywords: Knowledge;Congenital Deafness; ${ }^{\text {rd }}$ Trimester of pregnancy;ANC frequency;COVID-19.

\section{Introduction}

One of the causes of congenital hearing loss that occurs in newborn due to factors that affect pregnancy, at birth, and after bird [1]. Congenital deafness is often associated with pregnancy infection with viruses such as rubella or cytomegalovirus (CMV) for every live birth rate. Congenital deafness is related to hearing loss. One of the most common hearing problems in children is congenital deafness. In Indonesia, prevalence of hearing loss is $4.2 \%$ and the prevalence of congenital deafness is $0.1 \%$ [2]. The risk of congenital deafness increase tenfold if the child is born with low birth weight or infection in pregnant women. Risk factors for hearing loss can be due to prenatal, perinatal, and postpartum factors. Risk factors affecting the incidence of congenital hearing loss are maternal fetal infection, family history of hearing loss, gestational diabetes, low birth weight, premature birth, hyperbilirubinemia, asphyxiation at birth, and mechanical ventilation for more than five days. Infants with one risk factor are 10.1 times more likely to have hearing loss than infants without risk factors, infants with two risk factors are 12.7 
times more likely to have hearing loss, and infants with three risk factors are more likely to have hearing loss do 63.2 times hearing loss [3]. This is one reason why the risk of hearing loss continues to increase every year. The most common non-genetic cause of hearing loss and neurological disorders in children is congenital cytomegalovirus (CMV) infection [4]. Hearing function plays an important role in intellectual and social development during childhood, if the hearing is impaired it will affect children's personal and social health and effect speech and language development in children [5].

Pregnant women need to know things related to the prevention of congenital deafness and the spread of congenital deafness to reduce the risk of congenital deafness. Prevention that can be done to prevent the risk of congenital deafness is to perform ANC regularly. One of the goals of the ANC monitoring the course of pregnancy and ensure the health of the mother and baby's growth and development, regular ANC it can detect early complications of fetal development during pregnancy, such as intrauterine growth retardation (IUGR), small for gestational age (SGA), large for gestational age (LGA), and intrauterine fetal distress (IUFD) [6].

During the COVID-19 pandemic, pregnant women are one of the groups that must be more vigilant. Because the immune system of pregnant women is vurnerable to exposure to viruses. Pregnant women need to know what precautions to take. WHO estimates that about $60 \%$ of cases hearing loss are caused by preventable causes. These infections can be prevented by improving maternal health practices through regular ANC visits and screening for pregnancy complications. However, during the COVID-19 pandemic, pregnant women experience anxiety when going to check their pregnancy at health sevices. Anxiety is a feeling of worry, restlessness, and nervousness that can accompany and cause depression [7]. So that the anxiety experienced by pregnant women makes not achieving a good ANC can result in negative pregnancy outcomes [8].

The purpose of this study is analyze the relationship between the knowledge of pregnant women in the third trimester about congenital deafness with the frequency of antenatal care during the COVID-19 pandemic. The research hypothesis is that there is a relationship between knowledge about congenital deafness in third-trimester pregnant women with the frequency of antenatal care examinations during the COVID-19 pandemic.

\section{Method}

This study is an observational analysis of a cross-sectional approach. The population in this study was $2423^{\text {rd }}$ trimester pregnant women totaling 242 at the Nganjuk distric health center, East Java. The sampling technique used was purposive sampling and 110 samples of pregnant women in the third trimester were produced. The independent variable in this study was the knowledge of pregnant women about congenital deafness. The dependent variable is the frequency of antenatal care. Knowledge scale of ordinal data and measured using a questionnaire and frequency of antenatal cae with nominal data scales was measured using secondary data from the $\mathrm{MCH}$ book for pregnant women. Data collection was carried out in August-September 2021 starting from the determination of the research sample. Respondents' knowledge was measured using a questionnaire. $\mathrm{MCH}$ handbook to measure the frequency of antenatal care for pregnant women. After data is collected, the data is processed and analyzed using the chi-square test with the help of the SPSS computer program. 


\section{Result}

Responden in this study amounted to 110 respondents of third-trimester pregnant women. The following table describes the general description of the characteristic of third-trimester pregnant women who are research respondent:

Table 1 characteristic of pregnant women in trimester 3

\begin{tabular}{llll}
\hline Characteristics & & N & \% \\
\hline Mother's Age & $<20$ years old & 1 & 0.9 \\
Last education & 20-35 years old & 98 & 89.1 \\
& $>35$ years old & 11 & 10 \\
No school & SD & 0 & 0 \\
SMP & 4 & 3.6 \\
SMA/SMK & 18 & 16.4 \\
& Akademy/College & 61 & 55.5 \\
& IRT & 27 & 24.5 \\
& Entrepreneur & 78 & 70.9 \\
& Teacher & 17 & 15.5 \\
& Student & 7 & 6.4 \\
\hline & Factory employee & 2 & 1.8 \\
\hline
\end{tabular}

From table 1 almost all the ages of pregnant women are in the range of 20-35 years, as many as 98 pregnant women (89.1). the majority of pregnant women's education was at the SMA/SMK level as many as 61 pregnant women (55.5\%). Most of the pregnant women do not work (IRT) as many as 78 $(70.9 \%)$.

Table 2 knowledge or $3^{\text {rd }}$ trimester pregnant women about congenital deafness

\begin{tabular}{lcc}
\hline Knowledge & N & $\%$ \\
\hline Not enough & 31 & 28.2 \\
Enough & 25 & 22.7 \\
Good & 54 & 49.1 \\
Total & 110 & 100.0 \\
\hline
\end{tabular}

From table 2, it can be seen that almost half of pregnant women in the third trimester have good knowledge about congenital deafness as many as $54(49.1 \%)$ and as many as $31(28,2 \%)$ mothers little knowledge about congenital deafness. 
Table 3 frequency of antenatal care during the COVID-19 pandemc

\begin{tabular}{lcc}
\hline Frequency antenatal care & $\mathbf{N}$ & \% \\
\hline Not in accordance & 84 & 76.4 \\
In accordance & 26 & 23.6 \\
Total & 110 & 100.0 \\
\hline
\end{tabular}

From table 3 it is found that almost all pregnant women perform ANC during the COVID-19 not following the minimun rules for ANC visits as many as $84(76,4 \%)$.

Table 4 relationship between knowledge of pregnant women about congenital deafness and the frequency of antenatal care Knowledge about congenital Frequency antenatal care deafness

\begin{tabular}{lccccc}
\hline & \multicolumn{2}{c}{ Non-standard } & \multicolumn{2}{c}{ Standard } & \multicolumn{2}{c}{ Chi-square Test } \\
& $\mathbf{N}$ & $\boldsymbol{\%}$ & $\mathbf{N}$ & $\mathbf{\%}$ & $\mathbf{p}(\mathbf{s i g})$ \\
\hline Not enough & 4 & 3.6 & 27 & 24.5 & 0.005 \\
Enough & 2 & 1.8 & 23 & 20.9 & \\
Good & 20 & 18.2 & 34 & 30.9 & \\
\hline
\end{tabular}

The result of the analysis of the relationship the knowledge of pregnant women in the third trimester about congenital deafness and the frequency of antenatal care examinations during the COVID-19 pandemic were obtained as many as $20(18.2 \%)$ mothers with good knowledge, conducting ANC visits according to the minimum rules. However, as many as 34 (30.9\%) pregnant women with good knowledge made ANC visits who did not comply with the minimum rules. The result of the chi-square statistical test obtained a p-value of $0.005(\mathrm{p}<0.05)$, so it can be concluded that there is a relationship between the knowledge $3^{\text {rd }}$ trimester pregnant women about congenital deafness and the frequency of antenatal care during the COVID-19 pandemic.

\section{Discussion}

The relationship knowledge of third trimester pregnant women about congenital deafness and frequency of antenatal care during the covid-19 pandemic resulting in a p-value $=0.005 \mathrm{p}(\mathrm{sig})<0.05$ Therefore, it can be interpreted as having a link between the knowledge of pregnant women in the third trimester about congenital deafness with the frequency of antenatal care during the COVID-19 pandemic. According to [9] what affect the knowledge of pregnant women with ANC visits sre age, education, and the surrounding environment. Environment factors greatly affect the mother because the environment is the whole situation around humans. Currenly, the whole world is in shock with the emergence of a new virus, namely the coronavirus with a new type called SARS-CoV-2, and the disease Coronavirus disease 2019 (COVID-19). WHO declared this outbreak a pandemic because it spread rapidly to various countries. During the COVID-19 pandemic, the anxiety of the entire world population, especially pregnant women, increased, so that pregnant women were afraid and anxious to make ANC visits to health services [10]. One thing that very often causes anxiety and fear related to COVID-19 in pregnant women is visits to health services for ANC [11]. In general, anxiety that occurs in pregnant women can it affects the health of both the mother and fetus. During the pandemic, the incidence of anxiety in pregnant women increased, so that pregnant women did not routinely perform ANC, and the problem required further handling, to reduce the negative impact on the welfare of the mother and fetus [12]. Congenital 
deafness can occur due to multiple risk factors both in pregnant women who have a family history of hearing loss, infection during pregnancy by toxoplasmosis, rubella, cytomegalovirus, herpes, syphilis, hepatitis-B and infection with Human Immunodeficiency Virus (HIV). In this study, pregnant women experienced anxiety which led to decreased compliance in ANC visits. Hearing loss caused by causes can be prevented through relugar ANC visits and screening for pregnancy complications [13]. Therefore, providing maternal and neonatal services during epidemics should be a challenge to avoid risk factors for congenital hearing loss and other pregnancy complications. The COVID-19 pandemic has prevented some pregnant women from regularly attending ANC to health services. So that pregnant women can continue to perform ANC regularly and reduce the negative impact on the welfare of the mother and fetus, pregnant women can consult online or by telephone so that pregnancy checks can still be carried out for pregnancy screening and risk factors for congenital deafness. Antenatal care changes can also be tailored to the individual patient' condition. For example low-risk and high-risk pregnancies can carry out antenatal care visits as needed [14]. Pregnant women who are going to have their pregnancy checked for the first time must make an appointment in advance with health workers so that health services for pregnant women remain optimal even during the COVID-19 pandemic.

\section{Conclusion}

According to the result of the analysis and discussion, it found that there was a relationship between pregnant women's knowledge of congenital deafness and the frequency of antenatal care during the COVID-19 pandemic, the following conclusions were obtained: There is an important relationship between knowledge of third trimester pregnant women about congenital deafness and the frequency of antenatal care during the COVID-19 pandemic with $\mathrm{p}(\mathrm{sig})=0.005$ pregnancy check-up visits for pregnant women to health services during the COVID-19 pandmic to reduce risk factors for side effects that occur in the fetus. Pregnan women are expected to always pay attention to their pregnancy by routinely checking their pregnancy during the COVID-19 pandemic with strict protocols such as using masks, washing hands, and maintaining distance during pregnancy check-ups or online consultations via cellphones.

\section{Acknowledgements}

I thank the Nganjuk Health Center Nganjuk Regency, East Java for giving me permission to do research and thank you for the supervisor who has guided me during the research process and drafting the manuscript, thank you also to respondents who are willing to be my research respondents and friends in the same struggle who have helped during the research process.

\section{References}

[1] D. Nugroho, “Tuli Kongenital Diduga Akibat Infeksi Rubela dan Sitomegalovirus,” Medica Hosp. J. Clin. Med., vol. 2, no. 2, pp. 130-136, 2014, doi: 10.36408/mhjcm.v2i2.106.

[2] F. F. Tanuwijaya, N. Purnami, S. Prajitno, and R. Etika, "European Journal of Molecular \& Clinical Medicine Correlation between Prenatal, Perinatal, and Postnatal Factors with Congenital Hearing Loss," Ejmcm.Com, vol. 07, no. 10, pp. 2263-2274, 2020, [Online]. Available: https://ejmcm.com/article_6944_39ebce35cea75f868890cec6c4a03ee4.pdf.

[3] Fiona Widyasari, F. Paulina, Ahmad Hifni, Abla Ghanie, and Erial Bahar, "Risk Factors for Congenital Deafness in Pediatric Patients Who Underwent Otoaccoustic Emission (OAE) and Auditory Brainstem Response (ABR) Examinations in General Hospital Mohammad Hoesin Palembang, Indonesia,” Biosci. Med. J. Biomed. Transl. Res., vol. 5, no. 3, pp. 752-763, 2021, 
doi: $10.32539 / \mathrm{bsm} . v 5 \mathrm{i} 3.341$.

[4] C. L. Townsend, M. Forsgren, K. Ahlfors, S. A. Ivarsson, P. A. Tookey, and C. S. Peckham, "Long-term outcomes of congenital cytomegalovirus infection in Sweden and the United Kingdom," Clin. Infect. Dis., vol. 56, no. 9, pp. 1232-1239, 2013, doi: 10.1093/cid/cit018.

[5] Azwar, "Deteksi Dini Gangguan Pendengaran Pada Anak,” J. Kedokt. Syiah Kuala, vol. 13, no. 1, pp. 59-64, 2013, doi: 10.24815/jks.v13i1.3403.

[6] A. D. Mahendra, N. Y. Hidajaturrokhmah, and S. Anggraeni, “Analisis Kepatuhan Antenatal Care (Anc) Terhadap Kejadian Komplikasi Kehamilan Di Puskesmas Tiudan Kecamatan Gondang Kabupaten Tulungagung,” J. Ilm. Ilmu Keperawatan Indones., vol. 9, no. 04, pp. 673-680, 2019, doi: 10.33221/jiiki.v9i04.356.

[7] A. Kajdy et al., "Risk factors for anxiety and depression among pregnant women during the COVID-19 pandemic: A webbased cross-sectional survey," Medicine (Baltimore)., vol. 99, no. 30, p. e21279, 2020, doi: 10.1097/MD.0000000000021279.

[8] U. Akgor et al., "Anxiety, depression and concerns of pregnant women during the COVID-19 pandemic," Arch. Gynecol. Obstet., vol. 304, no. 1, pp. 125-130, 2021, doi: 10.1007/s00404-020-05944-1.

[9] N. Mahmud, "Efektivitas Kunjungan Anc Pada Masa Pandemi Covid-19,” vol. 3, pp. 67-73, 2021.

[10] Y. Yuliana, "Corona virus diseases (Covid-19): Sebuah tinjauan literatur," Wellness Heal. Mag., vol. 2, no. 1, pp. 187-192, 2020, doi: 10.30604/well.95212020.

[11] K. Sianipar, J. Aritonang, and W. S. Wahyuni, "Kecemasan Ibu Hamil Tentang Pelayanan Antenatal Care Di Era Pandemi Covid-19,” J. Kesehat. Masy. Dan Lingkung. Hidup, vol. 6, no. 1, pp. 28-31, 2021.

[12] JEAN-F. TOMB et al., "risk factors for anxiety and depression among pregnant women during the covid-19 pandemic," Nature, vol. 388, pp. 539-547, 2020.

[13] K. Neumann, S. Chadha, G. Tavartkiladze, X. Bu, and K. R. White, "Newborn and infant hearing screening facing globally growing numbers of people suffering from disabling hearing loss," Int. J. Neonatal Screen., vol. 5, no. 1, pp. 1-11, 2019, doi: 10.3390/ijns5010007.

[14] D. Refiani, Y. I. Dewi, and S. Utami, "Gambaran Perilaku Ibu Hamil dalam Melakukan Antenatal Care saat Pandemi Covid-19 di Puskesmas Rawat Inap Sidomulyo Kota Pekanbaru,” Heal. Inf. J. Penelit., vol. 13, no. 2, 2021, doi: 10.36990/hijp.v13i2.272. 